Tin Lemac

\title{
SISTEMATIZACIJA KRITIČKE RECEPCIJE I PITANJA POETIČKO-STILSKOGA OPISA PJESNIŠTVA MARIJE ČUDINE
}

dr. sc. Tin Lemac, tinlemac01@gmail.com, Zagreb

pregledni članak

UDK 821.163.42.09 Čudina, M.-1 rukopis primljen: 8. 3. 2017.; prihvaćen za tisak: 25. 5. 2017.

U ovom se radu osvrćemo na kritičku recepciju pjesništva Marije Čudine, koja se zbivala u drugoj polovici 20. i prvim godinama 21. stoljeća. Praćenje tekuće produkcije nastajanja tog pjesničkog projekta i formiranje njegove poetike rezultiralo je brojnim uvidima koji se ovdje usustavljuju kako bi se razlučila njihova interpretativna validnost. Uz kritički odnos i slijeđenje navedenih značajki postavljamo pitanja poetičko-stilskog opisa u trenutku kada je on zaokružen i upućujemo na interpretativne točke kojima bi se trebalo kretati sljedeće kritičko usustavljivanje. Rad je s kritičkim tekstovima pozitivističke provenijencije pri čemu se izlučuju njegove temeljne značajke, određuje njegov doseg i uspoređuje sa sličnim pojedinačnim ili sintetičkim prikazima Čudinina pjesništva kako bi se navedena validnost legitimirala.

Ključne riječi: Marija Čudina; kritička recepcija;poetičko-stilskimodel; interpretativna perspektiva

\section{Uvod}

Pjesništvo Marije Čudine popraćeno je nevelikim brojem kritičkih tekstova koji pokazuju tri dominantna pristupa. Prvi je impresionističko-esejistički koji se temelji na uočavanju estetike samog opusa, drugi kritičko-stilistički koji je iznjedrio neke bitne poetičke odrednice, a treći filozofski kojim su se neki njegovi aspekti pokušali usustaviti. Tijekom pola stoljeća te kritičke recepcije oni su pratili tekuću produkciju objavljivanja pjesničkih zbirki, dok su poneki i postquem objelodanili sintetičke značajke cjelokupnog opusa. U ovom ćemo se radu osvrnuti na svaki pojedini kritički tekst (stariji se mahom referiraju na pojedine zbirke, dok su mlađi usmjereni na sintetizaciju), odrediti njegove interpretativne dosege i izlučiti koje značajke donose za pjesništvo Marije Čudine. U 
slijeđenju poznatih interpretacijskih kategorija kao i kritičkom odnosu prema pojedinim njihovim aspektima izgrađujemo sustav pitanja glede postavki poetičko-stilskog opisa pjesništva Marije Čudine. Time pomičemo recepcijski tok tekstova o Čudininu pjesništvu i omogućujemo neko moguće buduće sintetičko objelodanjenje poetike i stilistike opusa.

\section{Sistematizacija kritičke recepcije}

Pjesništvo Marije Čudine jedan je značajan, ali nedovoljno zapažen projekt na sceni suvremenog hrvatskog pjesništva. Neke antologije hrvatskog pjesništva uopće ga ni ne spominju (Milićević, Šoljan 1966), dok se u ostalima pojavljuje sa svega nekoliko pjesama koje ne daju uvid u cjelinu opusa i raznovrsne preokupacije. Zlatna knjiga hrvatskog pjesništva Vlatka Pavletića (1971: 736-739) spominje tri pjesme iz prve pjesničke zbirke Nestvarne djevojčice (Čudina 1959), a to su: Treba brzo plakati (1959: 12), Nije važno što će plakati (1959: 22) i Dajte mi svoju ruku (1959: 39) i jednu pjesmu iz druge zbirke Čađ i pozlata (Čudina 1963) naslova Otkuda ova čudna ludost (1963: 34). Antologija hrvatskog pjesništva od davnine do današnjih dana Ante Stamaća (2007: 766767) donosi pjesmu Ne, ne mogu u ovom svijetu biti iz Nestvarnih djevojčica (1959: 33) i fragment Neobični preobražaj divlje duše iz žanrovskog hibrida Divlja duša (Čudina 1986: 45). Hrvoje Pejaković (1997: 288-293) u Antologiji suvremene hrvatske poezije donosi također prethodno navedene dvije pjesme i ciklus pjesama Bazilisk iz Čudinine pjesničke zbirke Tigar (1971: 42). Iako antologije ne predmnijevaju uvid u cijeli pjesnički opus i ovise o već kanoniziranim mjestima i kritičarskim preferencijama, iz ovih bi se podataka moglo zaključiti koliko je Čudinino pjesništvo slabo raspoznato kod antologičara. Vrijeme izdanja Pavletićeve antologije korespondira s godinom izdanja Čudinina Tigra, a autorica je predstavljena isključivo pjesmama iz prvih dviju navedenih zbirki. S obzirom na izbor pjesama, vjerujemo da se postavljaju kriteriji sentimentalnosti i emotivno-patosnog lirskog govora u središte pozornosti kojima se ovaj opus lišava svoje raznorodnosti i pokušava predočiti samo jednim po volji odabranim lirskim kriterijem. Ponavljanje jednakih pjesama u prethodnim antologijama koje nastaju poslije Čudinine smrti također reducira uvid u Čudinino pjesništvo jer izdvaja njezinu ranu fazu i fragment žanrovskog hibrida za koja su istraživanja još uvijek zdvojna radi li se uopće o lirici.

Književnopovijesna istraživanja također su nepravedno oštetila pjesnički opus Marije Čudine, a zanimljivo je da je njezin rad izostavljen i u Leksikonu hrvatske književnosti Vlahe Bogišića (2005). Spominju je samo književni povjesničari Miroslav Šicel (1997: 249) i Slobodan Prosperov Novak (2003: 75-77). Šicel je smješta u nasljedovanje nadrealističke poetike, a Novak naglašava njezinu izdvojenost iz nacionalne književne matrice i sudjelovanje u beogradskoj nadrealističkoj umjetničkoj skupini Mediale (naime, Marija Čudina je udajom za srpskog nadrealističkog slikara Leonida Šejku odselila u Beograd 1969. godine, ali je nastavila objavljivati u Hrvatskoj), ističe temu tijela, krhkosti i prolaznosti, mračnih stihova i pjesama, simboličke životinjske likove i arhetipske slike. Poetski je opus obilježio opskurnom mješavinom Kafkine i Borgesove slikovitosti i 
Camusovih pitanja o apsurdu. Kao i Šicel, smješta Čudinu u programatski nadrealizam. Nasljedovanje nadrealističke poetike i Čudinino mjesto u njoj preko grupe Mediale pronalazi i elaborira Vlatko Pavletić u sintetičkoj studiji Panorama hrvatske književnosti dvadesetog stoljeća (1965: 565).

Kritička recepcija ove poezije tiče se, kao što smo u prethodnom paragrafu kazali, prikaza pojedinih zbirki i sintetičkog usustavljenja u našoj suvremenosti. Prva zbirka Nestvarne djevojčice (Čudina 1959) naišla je na solidan kritički odjek. Slobodan Novak (1959: 331-332) govori o njoj kao o ritmu jedne gorke mladosti, rezigniranog tepanja $i$ šutnje. Njezinu tematiku i emotivni sloj pjesama obilježava efektnom esejističkom sintagmom da je tvrdi čovjek podjetinjio, dijete prerano otvrdlo. Semantički određujući doseg naslovne sintagme, govori da nisu opjevane nestvarne djevojčice, već su one metafora tematskih riječi od kojih izdvaja riječi ljubav, golubica, san, ptica, dječak i plakanje. U tematskoj klasifikaciji dotiče se odrednice ispovjednosti lirskog subjekta (stvarna ispovijed jedne stvarne djevojke, ražalošćena i razboljela slika djeteta). Stilski obilježava talent i nadahnuće kao izvorno, a slike i motive kao smisaoni slijed. Izmještenost iz tadašnjeg krugovaškog i razlogaškog horizonta obilježava time da ne zna za poetiku, koristi praktičan jezik i ritam i sintaksu uvrijeđena maženja koje se želi potužiti sebi. Time ističe govornu dimenziju poetske sintakse. Novak je u svojoj kritici elaborirao osnovne stilske značajke ove zbirke koji se tiču autonomnosti i autohtonosti pjesničke poetike, predmetno-tematskog sloja, emotivnog stanja lirskog subjekta i obilježja stihovne sintakse. Obilježivši ovo pjesništvo kao intimističko i ispovjedno, zadao je početnu poziciju njegove recepcijske putanje. Srećko Diana (1960: 331-332) također ne upliće Mariju Čudinu među generacijske pjesnike, govori o intimnoj drami djetinjstva kao tematskoj okosnici zbirke, s time u vezi ističe izvor traganja unutar sebe, život i sudbinu nestvarnih djevojčica kao poetsku konkretnost i svijet zatvoren u sebe. Stilistički detektira neobično suptilne slike i slikovne metafore te prodor poetskog materijala iz sna u javu. Time naglašava nadrealistički poetski materijal premda to izrijekom ne govori. Uzroke intimnoj drami nalazi u ratu i glasovima prošlosti kao faktorima izvanknjiževne zbilje, a pesimističku intonaciju stihova ne povezuje s kategorijom apsurda, već ljudskom konkretnošću i pitanjem ocrtavanja pjesnikove ličnosti. Tako, unosi oznaku ispovjednosti ove lirike koja izrasta iz intimizma, a ne Univerzalija što je također bitna interpretativna točka. Ivo Smoljan (1960: 60) ističe dihotomiju mladost - zrelost u navedenoj tematici i smisaonoj razradi zbirke, registrira spoznajnoemotivna stanja lirskog subjekta kao što su sanjarenje, strast, težnje, odvratnost, agonija, znatiželja, nestabilnost, sklonost prema bezvrijednom, nepravda, kriva valorizacija ljudske boli, govori o talentu koji je evidentan, ali nije dostigao zrelost i njegovu izmještenost iz generacijskog horizonta obilježava nezrelošću, a na estetskoj osi detektira zanatski stvorene metafore koje više kazuju o tehnici pisanja nego o samom stvaralačkom erosu. To dokazuje skladnim zvučanjem metafora, ali nedovoljnom integrativnošću na razini teksta kako bi se postigao efekt željena poantiranja. Ova stilistička kritika s primjesom estetičkog zapažanja donosi vizuru oko strukture teksta i metafore, ali to ne dokazuje na nekom od teorijskih modela. Pretpostavljamo da je riječ 
o autorskom dojmu koji je ostao teorijski neelaboriran. Uočavajući odnose retoričnosti i izražajnosti, govori o besprijekornoj dikciji, ali nedovoljno personaliziranom pjesničkom talentu koji se ne dokazuje i elaborira primjerima što također pripisujemo autorskom dojmu i iskustvu čitanja. U registriranju emotivnih stanja kao i u davanju konačne ocjene zbirke kao straha pred životom i izbjegavanja života prije nego što smo ga dostigli zamjećujemo subjektivističku projekciju kritičara u navedenu zbirku. Ta projekcija ideologizira samu tekstovnu strukturu i sprečava transparentniji autorski uvid u nj. Tonko Maroević (2005: 8-12) precizno određuje semantičnost naslova zbirke pri čemu leksem djevojčica simbolizira bolnu doživljajnost i ranjivost, a leksemom nestvarna signalizira se ontološka razina bića pri čemu se uspostavlja dihotomija prošlo - sadašnje. Prošlo se, preko figure Djetinjstva, interpretira diskurzivnim učinkom arkadijskog, a sadašnje boli, tj. camusovskom bačenosti u svijet. U tom sveobuhvatnom dijalogu sa svijetom nastaje Čudinina prva zbirka. Branko Bošnjak (2005: 12-16), govoreći o cjelini Čudinina pjesništva, naglašava kako nije riječ o isključivoj egzistencijalnoj ugroženosti, već i o intimnoj drami bića razdvajajući refleksivni i ispovjedni poetski signal. Razmatrajući subjektov odnos prema svijetu u cjelokupnoj Čudininoj poeziji, Petra Sigur Drnić (2005: 25) govori kako u Nestvarnim djevojčicama postoji oblikovanje paralelnog svijeta koji supostoji u subjektovu opisu i nije jednak svijetu na drugom polu spomenute dihotomije. Time se problematizira značenje subjekta i ukazuje na njegovu slojevitost koja nadilazi dihotomijsku polarizaciju. Cvjetko Milanja u prikazu pjesništva Marije Čudine (2001: 177) ističe zbirku Nestvarne djevojčice (Čudina 1959) kao zrelo ostvarenje, postavlja Čudinino pjesništvo kao premosnicu krugovaškog i razlogaškog kruga i unosi biografizam temom subjektova tijela kojem prijeti rasap što tumači batajovsko-sparagmatičnom koncepcijom. Entitet svijeta uvrštava u Čudinine mračne figure razmatrajući ga kroz optiku intimne drame i egzistencijalističkih toposa. Time ukazuje na složenost Čudinina subjekta i same dihotomijske relacije.

Druga Čudinina zbirka Čađ i pozlata (Čudina 1963) nije naišla na toliko snažnu kritičku recepciju. Milan Komnenić (1963: 12) smješta Čudinu u razlogaški pjesnički horizont hvaleći osobitosti njezina pjesničkog jezika i povezujući je s Igorom Zidićem, Matom Ganzom, Zvonimirom Mrkonjićem, Tonkom Maroevićem i Danijelom Dragojevićem. O navedenoj zbirci govori kao o evolutivnom pomaku od Nestvarnih djevojčica (Čudina 1959) izdvajajući sakralnu atmosferu, patetični retorski ton ode i himne i biblijsku ekstazu. Versifikacijski obrasci aleksandrinca i verseta ne podržavaju razvijanje $i$ sažimanje, pa se atmosfera nadaje svečanom i zagrobnom što Komnenić esejistički naziva maglovitim isparavanjem iz jezičnog lonca. Stilističko-kritičkim perom govori o prenaglom skoku u narativnost čime kvaliteta poezije pada, ali i ekspresivnoj snazi ženskog temperamenta. Nedostatcima ovog poetskog govora smatra eksplikativnost, jeftinu i bizarnu inspiraciju, variranje jednog te istog impulsa i emfatično dug stih. Detektirajući jezične obrate i blagu poetsku mistiku diskurziviranu kroz okultno, iracionalno i proročko, inspiracijsko središte ove Čudinine zbirke nalazi u crnačkoj plastici i primitivnoj poeziji naglašavajući minucioznost i dražesnost. Ovi stilističko-estetički uvidi govore o prijelazu pozicije lirskog subjekta i mijene entiteta svijeta, te spomenute poetičke značajke same 
zbirke kojom se struktura ovog pjesništva usložnjava. Dalibor Cvitan (1968: 211-212) također naglašava patetičan ton i invokaciju i dug stih i mijenu ove poezije od eidetičkog doživljavanja svijeta oko sebe i u sebi prema deskriptivnoj poeziji koja vodi u rasplinutiju strukturu stiha, verbalnu maštovitost i estetičku dekorativnost. Petra Sigur Drnić (2005: 26) naglašava nadmoć smrti i zagrobnu ikonografiju zbirke ističući mijenu subjektove suočenosti sa smrću i kaosom svijeta u egzistencijalističkom kodu. Cvjetko Milanja (2001: 178) također kritički uočava prežestoku i prenapadnu pjesničku građu koja proizlazi iz guste metaforike i velikog emotivnog investiranja lirskog subjekta. Iako je ova zbirka mahom obilježena estetičkim uvidima i nije dobila visoke kritičke ocjene, detektirane su evolutivne mijene i bitne poetičke značajke čije izvorište postoji i na polu subjekta i svijeta $s$ obzirom da oba entiteta dobivaju složenu značenjsku gradnju. Patetičan ton jest estetska kvalifikacija, ali i daje stanovitu poetičku dimenziju sagledavanja kao i dug stih koji su stariji kritičari pronašli kao nedostatak. Poetičke odrednice svijeta kao mistične, okultne i proročke bacaju istraživačko svjetlo na strukturu tematsko-značenjskih prostora ove zbirke.

Pjesnička zbirka Pustinja (Čudina: 1966) predstavlja stanovitu mijenu u pjesničkom opusu Marije Čudine zbog svoje poematične strukture. Dalibor Cvitan (1968: 211212) uočava da je riječ o lirskom meditativnom lutanju i metafizičkoj poeziji koja se suprotstavlja diskurzivnom mišljenju empiričara $\mathrm{i}$ da se u elegijskom tonu prostire ničeanska pustinja u svojstvenim kategorijama. Aleksandar Ristović (1967: 4) uočava danteovski podtekst i signalizira kako se radi o isforsiranoj verziji Pakla koja počiva na praznoj retoričnosti, narativnim frazama i formalizmu poetizacije. Tonko Maroević (1971: 861) govori kako je naslovni leksem pustinja metafora difuznosti i promjenjivosti poetskog svijeta i kako predstavlja beznadni univerzum u koji je sve uronjeno. Branko Bošnjak (2005: 14) govori o metafori pustinje kao svijesti o prolaznosti. Petra Sigur Drnić (2005: 28) postavlja tezu o mijeni ništavila koje je već zahvaćeno prethodnom zbirkom. Orijentirajući se na pustinju kao egzistencijalistički i kršćanski topos, Cvjetko Milanja (2001: 180) tumači pjesme Kierkegaardovim toposom zebnje ističući emotivno povišenu poziciju lirskog subjekta koja je semantički izjednačena s kognitivnim stajalištem i samim time podrazumijeva kvalifikaciju Drugog. Iako su Ristovićeve kritičke opaske o poetskom formalizmu pretjerane, navedene teze stvaraju vrlo razvidan referencijalni okvir sagledavanja poetičkog razvoja ovog pjesništva.

Pojavom pjesničke knjige Tigar (Čudina 1971) Čudinina poezija dobiva animalističke simboličke motive i time se usložnjava njezina poetička i predmetna struktura. Tonko Maroević (1971: 862) postulira tezu da se radi o tigru Drugoga (svijeta koji je stavljen u opreku prema subjektu), te kako nije interpretativno valjano povezivati Čudinina tigra s poznatim i kanoniziranim Blakeovim i Borgesovim tigrom. Također, govori da se radi o zbirci poslanica koje poetički kvalificira eksplikativnim nitima i okvirima snoviđenja i zaborava koji podržavaju odveć poetična i retorička mjesta. Čudinin poetski govor također definira prostorom poetske autonomije. U jednom kasnijem tekstu (Maroević 2005: 11) osvrće se na bestijarij prisutan u Tigru (Čudina 1971) i govori o njegovoj polazišnoj dihotomiji. Naime, riječ je o bajkovitosti s jedne i 
okrutnosti s druge strane, te kako određene životinje, oponašajući govor anđela, predstavljaju humane entitete i da cjelokupnost animalističke tvorbe predstavlja dijalog sa svijetom koji se očituje u kodu feminilne infantilnosti i traumatičnog iskustva koje se psihološki prorađuje oniričkim, fantastičkim i nadrealističkim iskazima. Petra Sigur Drnić (2005: 30) ističe navedenu zbirku kao središnju zbirku Čudinina opusa, a tigra tumači kao simbol alter ega duše koja se izdiže iznad ništavila. Iskustvo naslućivanja i istinski nesvedivi uzrok našeg bića predstavlja kao dominantnu filozofsku strategiju koja se diskurzivira Čudininom poezijom. Bestijarij u Tigru (Čudina 1971) promatra i Tea Benčić Rimay (2005: 143) uvodeći pojam ljudskog identiteta u vezu sa životinjama, a borbu $\mathrm{s}$ tigrom tumači kao borbu $\mathrm{s}$ pjesmom shvaćenom $\mathrm{u}$ baudelaireovskom poetičkom kodu. Roberta Brayer (2008: 147) govori o ovoj zbirci kao o pokušaju stvaranja novog svijeta viđenog instinktima i detektira simboličku putanju razvoja motiva tigra od pjesme i ciklusa do motiva i simbola. Cvjetko Milanja (2001: 180) tumači životinje prisutne u bestijariju kao reprezentante konceptualnih ideja i eliotovske simbole ljigavosti i „pustinjskosti” koji predstavljaju dodir ovostranog i onostranog, stvarnog i metafizičkog. Sumiranjem navedenih teza, dobivamo tumačenje životinjskih motiva u razvoju egzistencijalistički obilježene Čudinine poetike. Metapoetički književni kod potrebno je temeljitije tekstualno propitati jer su njegove elaboracije suviše esejističke i ne pretendiraju teorijskoj utemeljenosti.

Pjesničkom zbirkom Paralelni vulkani (Čudina 1982) dobivamo cjeloviti i elaborirani opis svijeta u pjesništvu Marije Čudine koji se opisuje teorijskim elementima gnosticizma (Kiš 1982: 121-130). Umjesto šetnje po baudelaireovskoj šumi simbola, Čudinin lirski subjekt kreće se u svijetu koncepata, ne pjeva i ne nariče, već je tiho rezigniran. Detektirajući metafizičku platonovsku faunu i gnostičkog tigra kao simbola melankolije i nesavršenosti svijeta, Danilo Kiš utvrđuje gnostički koncept svijeta u Čudininoj poeziji koji potkrepljuje stihovima i esejistički elaborira kao košmarne predjele lucidnosti nastanjene utvarama. Kao prilog navedenim tezama govori kako gnostička poezija koja se definira metaforom pada počiva na gnostičkim formulama i jednostavnosti izraza. Suprotstavlja se tezi o njezinoj nadrealističnosti koju je ustanovila ranija kritika jer osim navedena gnosticizma, uočava i manihejsku strukturu poetskog svijeta i egzistencijalističke momente. Dalibor Cvitan (1983: 119-120) također ističe Kiševe kategorije i zbirku obilježava sintaktičkim piruetama kojima se ne može dati nomenklatura. Osim već spomenutih manihejskih simbola, Cvitan utemeljuje subjekt u Paralelnim vulkanima (Čudina 1982) religijskim ateizmom i ontološkom dramom krivo postavljenog svijeta.

Žanrovski hibrid Divlja duša (Čudina 1986) problematizira poetiku samog pjesničkog stvaranja, te postavlja temeljna pitanja pisanja kao mogućnosti diskurziviranja svijeta ili pisanja prema usudu. Time se vješto postavljaju metapoetičke teme pisanja i subjekta koje je već iznjedrio i elaborirao Hrvoje Pejaković (1989: 98). Cvjetko Milanja (2001: 181-182) definira tu knjigu kao autohermenutičko „sanjarenje” o divljoj duši i njezinim životinjskim preobrazbama, žanrovski je definira kao mješavinu esejističkog, komentatorskog i autopoetičkog diskurza koje poetički počiva na arhetipiji i simulaciji prvobitnih stanja. 


\section{Pitanja poetičko-stilskog opisa}

Kritička recepcija nevelikim je brojem tekstova i zapažanja dala uvid u razvojne faze Čudinina pjesništva i istakla poetičke, stilske, filozofske i estetičke pozicije u sagledavanju. Praćena je tekuća produkcija, a tekstovi složenijih teorijskih dimenzija dolaze tek nakon nastanka opusa revidirajući ili proširujući navedene zasade iz kritičkih tekstova. Kako se u budućnosti kanimo pozabaviti cjelovitim poetičko-stilskim opisom ovog pjesničkog projekta, stavčano iznosimo silnice sagledavanja ovog pjesništva $s$ proširenjima prethodnih interpretacija i ispravljanjima nekih nedosljednosti.

- propitivanje izmještenosti Čudinina pjesništva u horizontu razvojnih mijena novije hrvatske lirike, pitanje prijelaza iz krugovaškog u razlogaški horizont, detektiranje poetičkih strategija i stilski opis

- utjecaji europske i svjetske književnosti u Čudininoj lirici

- Čudinina lirika u kontekstu suvremene hrvatske ženske lirike

- nadrealizam u Čudininu pjesništvu (pitanja koja su već otvorena analizom Cvjetka Milanje (2001: 180) i Vlatka Pavletića (1965: 565), pitanje je radi li se o formativnom ili sadržajnom nadrealizmu, analiza počiva na detekciji poetskih slika i semantičkoj analizi njihova materijala kao i pomno čitanju sintagmatske oblikotvorne metaforike, funkcionalna analiza kreće se u domeni određivanja poetičkog nadrealizma ili isključivo retoričke funkcije nekih sintagmi ili poetskih iskaza

- lirski subjekt Čudinina pjesništva (pitanje njegove unifikacije ili mijena od zbirke do zbirke, teorijski opis subjektne relacije melankolijom (Sorel 2005: 20-25), preciznija određenja u semantičkom sloju poetskih iskaza)

- svijet u Čudininu pjesništvu (egzistencijalistički, ničeanski ili gnostički svijet; temeljita pojmovna i tekstualna analiza i precizno određenje razlika, moguće proširenje)

- narativna poetska sintaksa Čudinina pjesništva (besjedovni stih i njegova semantizacija, prikladnost za takav tip tematizacije)

- hiperbola kao trop i figura (dominantni semantički, stilski i pragmatički konstituens Čudinina pjesništva)

- misaonost Čudinine lirike (od ispovjednog i osobnog do refleksivnog i općeg)

- izvanknjiževni faktori (biografizam kao točka sagledavanja nastanka opusa)

- tijelo u Čudininu pjesništvu (pitanje rasapa i ugroženosti kao interpretativnih perspektiva)

- emotivna analiza Čudinina pjesništva (emotivno-patosni govor lirskog subjekta, određenje njegove složenosti i semantičkog regulativa za postavljanje poetičkih silnica)

- poetičko detektiranje i stilsko obilježavanje raznovrsnih imaginarija u Čudininoj poeziji (onostrano, zagrobno) 


\section{Zaključak}

Ovim je radom izvedena analiza kritičke recepcije Čudinina pjesništva zbog mogućnosti sagledavanja raznovrsnih interpretativnih perspektiva, usustavljenja dobivenih uvida i kritičkom razmatranju pojedinih uvida koji se pojavljuju u nekom danom tekstu i u kontigenciji s razvojnim putem same kritičke recepcije. Analiza navedenih uvida iznjedrila je potrebu isticanja određenih kategorija i teorijskih perspektiva koje trebaju biti obrađene u poetičko-stilskom opisu kako bismo dobili cjeloviti uvid u Čudinino pjesništvo i pokušali riješiti neke nedoumice koje još uvijek postoje u kritičkom i teorijskom diskurzu o njemu. Prije svega, riječ je o detektiranju izmještene pozicije, višeslojnosti pozicije biografskog subjekta koji se odaje tijelom i vlastitom emotivno-patosnom pozicijom i egzistencijalizmu i nadrealizmu kao poetotvorbenim kategorijama. Temeljna problematika Čudinina pjesništva stoji u iznimno složenoj relaciji subjekt - svijet kojoj je tek potrebna temeljita analiza kako bismo jasnije postavili poetičke i stilske kategorije i dobili koherentniji opis ovog sjajnog i složenog pjesničkog projekta.

\section{Izvori}

Antologija hrvatske poezije (ur. Nikola Milićević i Antun Šoljan) (1966) Zora, Zagreb. Antologija hrvatskoga pjesništva: od davnina do naših dana (sastavio Ante Stamać) (2007) Školska knjiga, Zagreb.

Antologija suvremene hrvatske poezije (sastavio Hrvoje Pejaković) (1997) Društvo hrvatskih književnika, Zagreb.

Čudina, Marija (1959) Nestvarne djevojčice, Mladost, Zagreb.

Čudina, Marija (1963) Čađ i pozlata, Nolit, Beograd.

Čudina, Marija (1966) Pustinja, nezavisno izdanje, Beograd.

Čudina, Marija (1971) Tigar, Nakladni zavod Marko Marulić, Split.

Čudina, Marija (1982) Paralelni vulkani, BibliotekaTeka, Grafički zavod Hrvatske, Zagreb.

Čudina, Marija (1986) Divlja duša, Grafički zavod Hrvatske, Zagreb.

Frangeš, Ivo (1987) Povijest hrvatske književnosti, Nakladni zavod Matice hrvatske, Zagreb. Leksikon hrvatske književnosti (ur. Vlaho Bogišić) (1998) Naprijed, Zagreb.

Novak, Slobodan Prosperov (2004) Povijest hrvatske književnosti (svezak III.), Marjan tisak, Split.

Šicel, Miroslav (1997) Hrvatska književnost 19. i 20. stoljeća, Školska knjiga, Zagreb.

Zlatna knjiga hrvatskog pjesništva (sastavio Vlatko Pavletić) (1971) Nakladni zavod Matice hrvatske, Zagreb. 


\section{Literatura}

Benčić Rimay, Tea (2005) I bude šuma (mala studija o poeziji žena), Altagama, Zagreb.

Brayer, Roberta (2008) „Vratiti se čuđenju”, Autsajderski fragmenti, br. 3, sv. 5/6, str. 138-149.

Bošnjak, Branko (2005) „Marija Čudina i pjesništvo nestvarnih djevojčica”, Riječi, br. 1-2, str. 12-16.

Cvitan, Dalibor (1983) „Marija Čudina, Paralelni vulkani”, Republika, br. 6, str. 119-120.

Diana, Srećko (1960) „Marija Čudina, Nestvarne djevojčice”, Mogućnosti, br. 4., str. 331-332.

Diana, Srećko (1964) „Poetski svijet Marije Čudine”, Mogućnosti, br.5, str. 331-332.

Donat, Branimir (1968) „Retorika metafizičke poezije”, Kolo, br. 3, str. 211-212.

Kiš, Danilo (1982) Izgnanstvo i kraljevstvo Marije Čudine, u: Paralelni vulkani (1982: 121-130), Grafički zavod Hrvatske, Zagreb.

Komnenić, Milan (1963) „Patetični akordi Marije Čudine”, Delo, br. 12., str. 176-178.

Maroević, Tonko (1971) „Tigar drugoga”, Kolo, br. 8, str. 861-862.

Maroević, Tonko (2005) „Djevojčica sa životinjama”, Riječi, br. 1-2, str. 8-12.

Milanja, Cvjetko (2001) Hrvatsko pjesništvo od 1950. do 2000. (II. tom), Altagama, Zagreb.

Novak, Slobodan (1959) „Marija Čudina: Nestvarne djevojčice”, Krugovi, br. 4., str. 331-332.

Pavletić, Vlatko (1965) Panorama hrvatske književnosti dvadesetoga stoljeća, Stvarnost, Zagreb.

Ristović, Aleksandar (1967) „Marija Čudina, Pustinja”, Književne novine, br. 18, str. 4.

Smoljan, Ivo (1960) „Pod svodom iracionalnog - da se izbjegne život”, Republika, br. 2/3, str. 60 .

Sigur Drnić, Petra (2005) „Pjesništvo Marije Čudine”, Riječi, br. 1-2, str. 25-30.

Sorel, Sanjin (2005) „Maniristička melankolija Marije Čudine”, Riječi, br. 1-2, str. 20-25. 


\section{SUMMARY}

\section{Tin Lemac}

\section{SYSTEMATIZATION OF CRITICAL RECEPTION AND ISSUES OF POETIC AND STYLISTIC DESCRIPTION OF MARIJA ČUDINA'S POETRY}

Marija Čudina's poetry represents one of famous, but not well known projects on the recent Croatian poetry scene. Her beginnings are related to the poetic horizon of the literary journals Circles and Reason and the poetry by other authors reveals her growth in the manner of her selfconsistency. The reason for her nonbelonging to the generation modes is partially related to her private life in Belgrade after she married Leonid Šejka and some antipoetic suggestions which she has presented in her book Wild soul (Čudina 1986). Her first book Imaginary girls (Čudina 1959) was well received by the critics, and some of them (such as Cvjetko Milanja) assume that this book is one of her most powerful books from the poetic point of view. Her poetry is described in terms of existentialism, melancholy and Gnosticism. Some of her works are existentialist (explicated in the manner of Cioran, Beckett, Camus, as Milanja explained). Melancholy is the main characteristic of the already mentioned Wild soul (Sanjin Sorel has explained this in one of his papers). Some critics (e.g. Danilo Kiš) explain the world in her poetry by using Gnosticism. In this paper we deal with the critical reception of Marija Čudina's poetry which was published during the second half of the $20^{\text {th }}$ and the first years of the $21^{\text {st }}$ century. Following of the current production of this poetic project and the formation of its poetics have resulted in many insights which are here systematized so that we can analyse their interpretative validity. With critical distance and focusing on these issues, we analyse her poetic and stylistic description at a moment when this project is rounded and we suggest interpretative directions in which the future critical systematizations should go. We take a positivist approach to these critical texts and detect their basic values, evaluate their range and compare them with other individual or synthetic texts on Čudina's poetry in order to legitimise their validity.

Key words: Marija Čudina; critical reception; poetics and the stylistic model; interpretative perspective 